\section{Research Associations}

SIR,- The difficulties of the industrial research associations and of the Government in its approach to them ("Cooperative Research in Trouble", Nature, 231, 206 ; 1971) seem to me to stem from two basic weaknesses in the original concept of a research association to serve a particular industry.

The first of these is the not-talked-about but undeniable fact that if a firm has a really good idea for a new product or process, it will strive to develop this for its own sole use and exploitation and the last body it will want to know about it is its industry RA. This is the basis of the frequent complaint by RA staffs that discussion with members is a one-way affair. Thus an RA is only likely to get a good commercial idea either from within itself or from external sources other than its own industry and is largely cut off from what should be the main source of inspiration, the industry itself.

The second weakness is seen in those RAs (most of them) whose member firms are of very different sizes. The large firm, often with scientific resources larger than that of its RA, and the small firm with few or no qualified technical staff require quite different services from the RA which may find these demands very difficult to reconcile.

A better structure for many industries would be to have a technological institute or unit associated with a particular university or polytechnic. This would provide fundamental background knowledge, act as a specialist information centre, and do such secondary but essential tasks as standards and reference work, development of test methods and so on. Such an organization would better serve the requirements of the larger companies in complementing their own technical efforts and it would also create more of the desired university-industry contacts.

The small firm would derive some benefits directly from such a centre and more indirectly but most of its needs could be met by a less-specialized but more local source of scientific advice, something like an industrial counterpart of the National Agricultural Advisory Service, though this is an unhappy analogy to draw at the present time. Possibly an expanded Industrial Liaison Officer service could fill this role.

For myself, I view with wary scepticism the present push to make the RAs commercially viable and fear that any early success they may have may be due to their living off technical capital accumulated in the previous era. Further, I think that the basic faults in their constitution to which I have pointed will hinder them just as much in seeking sponsored research.

Yours faithfully,

ALAN Jobling

44 Luton Road,

Harpenden,

Hertfordshire

\section{Test Ban Loophole}

Sir,--Mr Scoville's letter (Nature, 231, 339 ; 1971) disputes your view that a completion of the Test Ban would "do away with the need for IAEA inspection to verify compliance with the NPT". He points out, surely rightly, that a "nonnuclear weapon nation that had unguarded fissionable material could proceed with a nuclear weapons programme without any nuclear tests" and that so far no first tests have been failures. Quite. But the IAEA safeguards on fissionable material only apply to that which is denominated "peaceful". Let the government of a non-nuclear weapon nation describe the uses to which its fissionable material is put as "military" and it escapes control. This loophole in the NPT exists to allow the construction of reactors for nuclear submarines, but the treaty's language gives blanket exclusion from control to all non"peaceful" programmes.

The Soviet Union, by the way, was reported in Le Monde recently as offering enriched uranium to the Federal Republic of Germany merely against a minister's word that it would be used for peaceful purposes.

Yours faithfully,

Mrs Elizabeth YounG

100 Bayswater Road,

London $W 2$

\section{Sickle Cell Research}

SIR,-The notes of your Washington correspondent (Nature, 231, 78; 1971) concerning research on sickle cell anaemia reflect a much publicized viewpoint, viz., that the development of a practical treatment for this disease has been "curiously slow". The politically useful implication is that this has been for want of research and lack of funds. One source of this belief lies with surveys of Federal grants in which the number of projects pertinent to sickle cell disease are judged by grant title. This kind of test is akin to rating dollars for Down's syndrome without reference, for example, to studies of the mechanisms of either meiosis or aneuploidy.

Your correspondent missed a chance to set the record straight. The severity and incidence of sickle cell disease have- for us-been well-springs of interest in haemoglobin centred research. We are not alone. For two decades the pages of Nature have illustrated the attention paid to haemoglobin by literally thousands of investigators. In particular, the regulation of biosynthesis and the relations between structure and function are probably better defined for haemoglobin than for any other molecule. We believe that many of these developments were prompted by the problem of sickle cell disease. We expect that the evolution of therapy for this disease will take cues from such studies. For the moment, we are conscious of the complexities encountered and it is no surprise to us that the sickling disorders cannot yet be cured. Contrary to your correspondent: the pathophysiological nature of these diseases is not well understood. We don't know how molecules of haemoglobin $\mathrm{S}$ aggregate; we don't know how the levels of $\mathrm{S}$ and the sometimes attendant-and palliative-foetal haemoglobin are controlled; we don't know whether the disease-in the United States today-really "kills half its victims before the age of 20", and we don't even know why they die.

Federal funds have been extensively and profitably used for studies of the abnormal haemoglobins and where the public has been led to believe otherwise the public has been misinformed. Our fear is that in the present clamour for delivery of medical care and in a climate of politically assigned research strategies, funds will be diverted from fundamental studies which may eventually lead to effective treatment.

Yours faithfully,

SAMUEL H. BOYer

Samuel Charache

C. LOCKard CONLey

The Johns Hopkins Hospital,

Baltimore,

Maryland 21205

\section{Kill the Billion}

SIR,--May I once again urge all authors to stop using the billion as a unit, and ask all editors to insist on converting billions, if authors still use them, to less ambiguous units. As a billion means $10^{12}$ in most of Europe and only $10^{9}$ in America, the possibilities of error are considerable. Those working with pesticides, where residues may occur within the range of $10^{-6}$ and $10^{-12}$, are the worst offenders.

\section{Yours faithfully,}

KenNeTH Mellanby

Editor, Environmental Pollution, Monks Wood Experimental Station, Huntingdon 